\title{
A CONTRIBUTION TOWARDS THE KNOWLEDGE OF THE EFFECT OF SMALL MAMMALS ON THE REGENERATION OF FOREST TREES IN SELECTED STANDS OF THE KELEČ UPLAND (CZECH REPUBLIC)
}

\author{
J. Suchomel
}

Received: July 14, 2007

\begin{abstract}
SUCHOMEL, J.: A contribution towards the knowledge of the effect of small mammals on the regeneration of forest trees in selected stands of the Kelečská pahorkatina Upland (district of Přerov, Czech Republic). Acta univ. agric. et silvic. Mendel. Brun., 2008, LVI, No. 1, pp. 267-270

Effects of small mammals were studied on the regeneration of trees in a forest reserve and on forest plantation in the area of the Kelečská pahorkatina Upland with a view to stands of European beech (Fagus sylvatica). Inspection of bark damage was carried out and artificial regeneration was markedly more susceptible to damage $(\mathrm{p}<0.01)$. Of the total number of monitored beech trees $57.5 \%$ were damaged in artificial regeneration compared to $12.7 \%$ in natural regeneration and $15 \%$ died as against $0 \%$. The only pest proved by trapping was Myodes glareolus although damage of tree bases could mean damage caused by species of the genus Microtus. With respect to the large crop of seeds (beech nuts) in 2006, it is possible to expect increase in the population of rodents in the next season and thus increased damage to trees. Results obtained show that it is very important to support natural regeneration and as for planting to minimize the herb layer cover in the vicinity of trees, which represents the optimum environment for the occurrence of rodents.
\end{abstract}

artificial regeneration, natural regeneration, small mammals, Myodes glareolus, Microtus spp.

Effects of small rodents on the artificial and natural regeneration are an always-discussed problem (HEROLDOVÁ, 1995; HEROLDOVÁ and ZEJDA, 1995; BEJČEK et al., 1999; BRYJA et al., 2001; HEROLDOVÁ et al., 2007 etc.) particularly at present, when the goal-directed transformation of unstable spruce monocultures to mixed forests occurs. Damage caused by small mammals to natural regeneration and plantings of mainly broadleaved species is often neglected or tolerated although it can be rather important. For example, in recent decades small rodents cause damage to 5000 ha stands per year (ŠVESTKA et al., 1990). At present, however, urgency to protect trees from the damage increasingly occurs. One of possibilities to reduce the damage is to prefer natural regeneration, which is substantially more resistant from impacts of small rodents
(HEROLDOVÁ, 1995; BRYJA et al., 2001; HEROLDOVÁ et al., 2007). This fact could be also proved on the basis of preliminary studies within research on the small mammals damage of the Kelečská pahorkatina Upland where a similar study has not been carried out yet.

The objective of the paper was to determine the rate of the impact of small mammals on the regeneration of forests in the area of Forest District Valšovice (district of Přerov), which is the specialpurpose area of the Secondary Forestry School in Hranice na Moravě. The studied region is situated in the natural forest area No. 37 - the Kelečská pahorkatina Upland (in total 1003.47 ha) at the boundary-line of the Oderské and Hostýnské vrchy Hills. The aim of the research was to compare effects of rodents on artificial and natural regeneration. 


\section{MATERIAL AND METHODS}

In 2007, checking of the impact of rodents on forest trees was carried out in two plots of the studied area in order to determine actual damage after winter 2006. However, with respect to low populations of rodents in this period and nearly zero impacts, older browsing from previous years was evaluated, above all from the previous winter (2004/2005), when populations of rodents in 2004 were very numerous. The first studied plot was natural regeneration of beech in the forest reserve Dvorčák (49.5141806 N, 17.6887167 E), which is characterized by the natural structure of tree species with the predominance of beech (Fagus sylvatica). It refers to a seed stand aged 132 years. Beech predominates in the stand together with interspersed small-leaved linden (Tilia cordata), sessile oak (Quercus petraea), hornbeam (Carpinus betulus), and sycamore maple (Acer pseudoplatanus). All species mentioned above regenerate well. Dominant species of the herb layer are as follows: Lathyrus vernus, Convallaria majalis, Tithymalus amygdaloides, Polygonatum multiflorum, Petasites albus, Carex pilosa and Poa nemoralis. The second plot was an exclusion fence with beech planting at $1 \times 1 \mathrm{~m}$ spacing in a clear-felled area aged 12 to 22 years (49.30889 N, 17.41449 E). Calamagrostis arundinacea and Rubus fruticosus predominated in the herb layer of the planting.

At these localities, the height and diameter of young trees were determined ( $N=60$, old stand and $N=200$, planting) and each of the trees was checked with respect to damage caused by small rodents. In case of browsing, the damage was described in detail. In particular trees, height, diameter at the tree base, extent of damage $\left(<1 \mathrm{~cm}^{2}, 1-10 \mathrm{~cm}^{2},>10 \mathrm{~cm}^{2}\right)$, height of damaged places above the ground and vitality (living, dead). According to the stem height and diameter it was possible to estimate that the monitored artificial and natural regeneration were roughly of the same age (Tab. I). Significance of differences of mean values of extent of damage was tested by t-Test (Indepen- dent, by Groups) in the STATISTICA Cz programme. Trees were checked in the laid out line regardless of a species and, thus, in addition to the most numerous beech, ( $\mathrm{n}=167$, planting and $\mathrm{n}=55$, old stand), also other species were included into checking such as silver fir (Abies alba) ( $\mathrm{n}=19)$, narrow-leaved ash (Fraxinus angustifolia) $(\mathrm{n}=6)$, black alder (Alnus glutinosa) $(\mathrm{n}=5)$, sycamore maple (Acerpseudoplatanus) $(\mathrm{n}=1)$ and smallleaved linden (Tilia cordata) $(n=5)$. Thus, checking the higher number of trees than 260 was not realized because with regard to the original intention of checking the actual damage it was not considered to be economic by reason of the low impact of small rodents.

\section{RESULTS AND DISCUSSION}

In total, 260 trees were checked at the locality. Theinspection was aimed at beech, which is a species most preferred by small mammals (HEROLDOVÁ, 1995). Results obtained show the substantially higher rate of damage and death in artificial regeneration as against natural regeneration (Tab. I). These differences were highly significant $(t=4.342 ; \mathrm{p}=0.00002)$. Of the total number of monitored beech trees, $57.5 \%$ were damaged in artificial regeneration as against $12.7 \%$ in natural regeneration. There were $15 \%$ as against $0 \%$ dead trees and $28.1 \%$ as against $87.3 \%$ living healthy trees. The highest proportion of stem browsing accounted for browsing exceeding $10 \mathrm{~cm}^{2}$, which represented $32.3 \%$ trees in planting. In principle, the same proportion corresponded to browsing from 1 to $10 \mathrm{~cm}^{2}$ (31.1\%). Browsing $<1 \mathrm{~cm}^{2}$ was minor (3\%). In natural regeneration, browsing was found in the category of $1-10 \mathrm{~cm}^{2}$ and above $10 \mathrm{~cm}^{2}$, both participating in $7.3 \%$. Some 80 trees (47.9\%) showed gnawed stem bases, namely only in planting, which was almost half of all monitored trees attacked by rodents. With respect to the limited number of data, no more statistical evaluation could not be carried out, however, a difference in impact on the natural and artificial regeneration was very marked and thus informative.

I: Results of a detailed inspection aimed at browsing young beech trees in natural regeneration and planting at two localities

\begin{tabular}{|l|c|c|c|c|c|c|c|c|}
\hline Regeneration & $\begin{array}{c}\text { Mean } \\
\text { height } \\
\text { cm }\end{array}$ & $\begin{array}{c}\text { max. } \\
\text { min. }\end{array}$ & $\begin{array}{c}\text { sterm diameter } \\
\text { Mean } \\
\mathrm{cm}\end{array}$ & $\begin{array}{c}\text { sterm diameter } \\
\text { max. min. }\end{array}$ & $\begin{array}{c}\text { Stem } \\
\text { browsing } \\
\text { Mean } \\
\text { height }\end{array}$ & $\begin{array}{c}\text { Death } \\
\%\end{array}$ & $\begin{array}{c}\text { Mean } \\
\text { browsing } \\
\text { up to } \\
\text { height }\end{array}$ & $\begin{array}{c}\text { Death } \\
\%\end{array}$ \\
\hline Natural & 373.24 & 80 to 800 & 4.01 & 1 to 10 & 2.89 & 0.00 & 32.38 & 0.00 \\
\hline Planting & 300.06 & 80 to 700 & 4.26 & 2 to 10 & 12.10 & 15.00 & 36.82 & 24.00 \\
\hline
\end{tabular}

As for other species, damage caused by rodents was found in black alder (40\%) and sycamore maple; massive damage to silver fir (78.9\%) was caused by roe deer (Capreolus capreolus). Bark damage at the locality was probably caused only by Myodes glareolus, which was detected within trapping small mammals.

Of course, with respect to the registered damage found at the base of trees, also Microtus arvalis and
Microtus agrestis could be potential pests, however, these have not yet been found at the localities (SUCHOMEL, 2007). The way of damage to trees markedly differs in Myodes glareolus from the two species. Myodes glareolus is able to climb the trees and bark removing caused by the species is distributed along the tree height (HANSSON and ZEJDA, 1977). Sometimes, it is even the top part of trees where bark 
is of the best and finest quality (ZEJDA et al., 2002; HEROLDOVÁ et al., 2007). Voles of the genus $M i$ crotus are not able to climb the trees and thus, they damage trees in such a way that they gnaw away bark only at the ground, often even round about (HEROLDOVÁ, 1995; BRYJA et al., 2001). Thus, a tree intact at the first glance dies. Nevertheless, high snow cover in winter makes possible that the pests browse bark even higher above the ground when majority of the species occurs below the snow cover (HANSSON and HENTTONEN, 1985; BAXTER and HANSSON, 2001). According to the criterion we could conclude that trees coming from natural regeneration were damaged by Myodes glareolus whereas in plantings, $47.9 \%$ damage were caused by species of the genus Microtus, of course, direct evidence in the form of trapped individuals is not available. Trees damaged by small mammals could be even rather grown. For example, HEROLDOVÁ et. al. (2007) mention that in natural regeneration, trees up to a height of $4 \mathrm{~m}$ with the stem diameter up to $12 \mathrm{~cm}$ can be endangered.

The mixed vegetation of the herb layer created by dicotyledonous plants (mainly Rubus spp.) suitable for Myodes glareolus (ZEJDA et al., 2002) and rich grass vegetation with the occurrence of old dry grass suitable for Microtus agrestis (HEROLDOVÁ and ZEJDA, 1995; ZEJDA et al., 2002) corresponded to the potential occurrence of both Myodes glareolus and Microtus agrestis at studied localities. Species of voles mentioned above cause damage to regeneration manly at higher population densities reached at regular cyclic reproductions (MYLLYMÄKI, 1977; LAMBIN et al., 2000; BRYJA et al., 2001). Effective protection of stands requires knowing the food ecology of the pests showing a certain specialization making possible to use also bark of trees as the source of food. Generally, their food basis is, however, substantially more various. Myodes glareolus feeds mainly on plant food consisting of green parts of herbs, however, it consumes also seeds of trees and seedlings. In the period of food shortage in winter the species gnaws the bark of trees preferring broadleaved spe- cies (HOLIŠOVÁ, 1974; ZEJDA, et al., 2002). Voles of the genus Microtus feed on plant food and grasses predominate in their food (HEROLDOVÁ, 1992, 2000, 2002). They cause damage due to bark browsing in the winter season preferring also bark of broadleaved species (HEROLDOVÁ, 1995, 2002).

Considering the large crop of seeds (beech nuts) in 2006 it is possible to expect an increase in the populations of rodents in the next season, mainly of Myodes glareolus (PUCEK et al., 1993) and thus also increased damage to trees. Based on the results obtained, it is possible to conclude that forest reserves show evidently sufficient self-regulation mechanisms from excessive damage to natural regeneration (open canopy, absence of forest weed serving as a shelter, easy accessibility for predators) as against artificial regeneration by planting (dense forest weed as a suitable shelter for rodents from predators, considerable amount of food - young trees - on one place). Stands from artificial regeneration (planting) near reserves concentrate populations of rodents from neighbouring ("less suitable") natural stands. Thus, the aim of forest management is to support natural forest regeneration and in plantings to minimize the herb layer cover in the surroundings of trees (TICHÝ, 1978).

\section{CONCLUSION}

Based on the results obtained, it is possible to conclude that forest reserves show evidently sufficient self-regulation mechanisms from excessive damage to natural regeneration (open canopy, absence of forest weed serving as a shelter, densely connected cover of young trees, easy accessibility for predators) as against artificial regeneration by planting (dense forest weed as a suitable shelter for rodents from predators, considerable amount of food - young trees - on one place). Stands from artificial regeneration (planting) near reserves concentrate populations of rodents from neighbouring ("less suitable") natural stands.

\section{SOUHRN}

\section{Příspěvek k poznání vlivu drobných hlodavců na obnovu lesních dřevin ve vybraných porostech Kelečské pahorkatiny (okres Přerov, Česká republika)}

Byl sledován vliv drobných savců na přirozenou obnovu dřevin v lesní rezervaci a umělou obnovu ve výsadbě, v oblasti Kelečské pahorkatiny, se zaměřením na porosty buku lesního (Fagus sylvatica). Byla provedena kontrola ohryzu kůry, přičemž umělá obnova se ukázala jako podstatně náchylnější k poškození ( $p<0,01)$. Z celkového množství sledovaných jedinců buku bylo v umělé výsadbě poškozeno 57,5 \%, oproti 12,7 \% v obnově přirozené a odumřelých 15 \% ku 0 \%. Jediným odchytem potvrzeným škůdcem byl norník rudý (Myodes glareolus), i když ohryzy bází stromů mohou značit i poškození hraboši r. Microtus. Vzhledem k velké úrodě semen (bukvic) v r. 2006 lze další sezonu očekávat nárůst populací hlodavců a tím i zvýšené škody na dřevinách. Dosud získané výsledky ukazují, že při lesním managementu je velmi důležité podpořit přirozenou lesní obnovu a u výsadeb minimalizovat pokryv bylinného patra v okolí stromků, který představuje optimální prostředí pro výskyt hlodavců.

umělá obnova, přirozená obnova, drobní hlodavci, Myodes glareolus, Microtus spp.

The study was supported by financial means of the MSM 6215648902 and NAZV QH72075 projects. 


\section{REFERENCES}

BAXTER, R., HANSSON, L., 2001: Bark consumption by small rodents in the northern and southern hemispheres. Mammalian Review, 31, 1: 47-59.

BEJČEK, V., SEDLÁČEK, F., ŠŤASTNYY, K., ZIMA, J., 1999: Drobní savci v imisních oblastech Krušných hor: monitorování stavu prostředí a škody v porostech náhradních dřevin. Sborník konference "Problematika zachování porostu náhradních drevin v imisní oblasti Krušných hor, Most, 18.-19. 5. 1999: 83-88.

BRYJA, J., HEROLDOVÁ, M.,JÁNOVÁ, E., 2001:Vliv drobných zemních savců na obnovu lesa v NPR Kněhyně - Čertův mlýn. Beskydy, 14: 189-200.

HANSSON, L., HENTTONEN, H., 1985: Gradients in density variations of small rodents: The importance of latitude and snow cover. Oecologia (Berlin), 67: 394-402.

HANSSON, L., ZEJDA, J., 1977: Plant damage by bank voles (Clethrionomys glareolus /Schreber/) and related species in Europe. EPPO Bulletin, 7: 223-242.

HEROLDOVÁ, M., 1992: The diet of Microtus agrestis in immission clearings in the Krušné hory Mts., Folia Zoologica, 41, 1: 11-18.

HEROLDOVÁ, M., 1995: Poškozování lesní výsadby drobnými savci na imisních holinách Malého Smrku (Beskydy). Zpravodaj Beskydy, 7: 157-160.

HEROLDOVÁ M. \& ZEJDA J., 1995: Výsledky výzkumu společenstva drobných zemních savců v oblasti Beskyd s ohledem na poškozování lesních porostů imisemi. Zpravodaj Beskydy "Vliv imisí na lesy a lesní hospodáriství Beskyd", 7: 153-156.

HEROLDOVÁ, M., 2000: Food selection of Microtus agrestis in clearings of the Beskydy Mts. caused by air pollution. Abstracts from Rodens et Spatium, July 10-14, 2000, České Budějovice, Czech Republic: 151.
HEROLDOVÁ, M., 2002: Food selection of Microtus agrestis in air-pollution affected clearings in the Beskydy Mts, Czech Republic. Folia Zoologica (Supplement I "Rodens et Spatium"), 51: 83-91.

HEROLDOVÁ, M., SUCHOMEL, J., PURCHART, L., HOMOLKA, M., KAMLER, J., 2007: Drobní lesní hlodavci - významný faktor při obnově lesních porostů. Beskydy, 20: 217-220.

LAMBIN, X., PETTY, S. J., MACKINNON, J. L.: Cyclic dynamics in field vole populations and generalist predation. Journal of Animal Ecology, 2000, 69: 106-118.

MYLLYMÄKI, A., 1977: Demographic mechanisms in the fluctuating populations of the field vole $M i$ crotus agrestis. Oikos, 29: 468-493.

PUCEK, Z., JEDRZEJEWSKI, W., JEDRZEJEWSKA, B., PUCEK M., 1993: Rodent population dynamics in a primeval deciduous forest (Bialowieza National Park) in relation to weather, seed crop, and predation. Acta Theriologica, 38: 199-232.

SUCHOMEL, J., 2007: A study of the synusia of small terrestrial mammals (Insectivora, Rodentia) of the Kelečská pahorkatina Upland - Czech Republic. Acta Universitatis Agriculturae et Silviculturae Mendelianae Brunensis. LV, 5: 165-170. ISSN 1211-8516.

ŠVESTKA, M., HOCHMUT, R., JANČAŘÍK, V., 1990: Nové metody v ochranělesa. Praha: SZN, 208 s.

TICHÝ V., 1978: Myšovití (Muridae) v lesních porostech a ochrana proti nim. Práce VÚLHM, 1978, 52: 151-174.

ZEJDA, J., ZAPLETAL, M., PIKULA, J., OBDRŽÁLKOVÁ, D., HEROLDOVÁ, M., HUBÁLEK, Z., 2002: Hlodavci v zemédèlské a lesnické praxi. Praha: Agrospoj, $284 \mathrm{~s}$. 